\title{
Pendidikan Pancasila ditinjau dari perspektif filsafat (aksiologi)
}

\author{
Sunarni Yassa ${ }^{a, 1^{*}}$ \\ ${ }^{a}$ Program Studi PPKn, Universitas Cokroaminoto Palopo, Sulawesi Selatan \\ ${ }^{1}$ sunarniyassa@gmail.com \\ * korespondensi penulis
}

\begin{abstract}
ABSTRAK
Pendidikan berfungsi untuk mengembangkan kemampuan serta meningkatkan mutu kehidupan dan martabat manusia Indonesia dalam rangka upaya mewujudkan tujuan nasional. Pendidikan itu harus sejalan dengan tujuan pendidikan nasional yakni mencerdaskan kehidupan bangsa dan mengembangkan manusia Indonesia seutuhnya, yaitu manusia yang beriman dan bertaqwa terhadap Tuhan Yang Maha Esa dan berbudi pekerti luhur, memiliki pengetahuan dan keterampilan, kesehatan jasmani dan rohani, kepribadian yang mantap dan mandiri serta rasa tanggung jawab kemasyarakatan dan kebangsaan. Pancasila sebagai dasar negara Indonesia (ideologi) dan menjadi pedoman hidup, jiwa dan keperibadian bangsa Indonesia. Pancasila terkandung di dalamnya suatu pemikiran-pemikiran yang bersifat kritis, mendasar, rasional, sistematis dan komprehensif, sehingga sistem pemikiran ini merupakan suatu nilai. Oleh karena itu, Pancasila memberikan dasar-dasar yang bersifat fundamental dan universal bagi manusia baik dalam hidup bermasyarakat, berbangsa, dan bernegara. Bila dijabarkan dalam kehidupan yang nyata pada masyarakat, bangsa maupun negara maka nilai tersebut dijabarkan dalam suatu norma-norma yang jelas, yaitu norma moral dan norma hukum atau sistem perundangan yang berlaku di Indonesia. Dalam pemikiran filsafat aksiologi yang mengacu pada persoalan nilai, baik dalam konteks estetika, moral maupun agama, mengkaji dan menggali hakikat nilai itu. Maka melalui pendididkan Pancasila peserta didik diharapkan mampu memahami, menganalisis nilai-nilai Pancasila sebagai sumber acuan dalam menyusun etika kehidupan berbangsa bagi seluruh rakyat Indonesia dalam mencapai cita-cita dan tujuan nasionalnya, dan menjawab masalah yang dihadapi secara berkesinambungan.
\end{abstract}

Kata kunci: pendidikan, Pancasila, filsafat aksiologi

\begin{abstract}
Education aims at developing the ability and improving the quality of human's life and dignity in order to actualize the national objective. Education should be in line with national education objectives that are to educate nation's life and develop Indonesian' human wholly as faitful and pious man, has virtuous character, knowledge and skills, physical and spiritual health, steady and independent personality, also responsibility toward society and nationality. Pancasila is Indonesian ideology and becomes way of life, soul, and personality of Indonesian. Pancasila contains critical, basic, rational, systematic, and comprehensive thoughts, so this thought system is a value. Thus, Pancasila gives fundamental dan universal bases for human in social, national, governmental life. When verified in real life at society, nation, or government, the value is enlightened in obvious norms, namely morality norm and law norm or law system applied in Indonesia. Axiology philosophycal thought which refers to norms' issue in the context of aesthetic, morality, and religion studies and explores the nature of that values. Then, through civic education, learners are expected to be able to comprehend, analyze the values of Pancasila as a reference in establishing national life ethics for all Indonesian citizens in achieving national desire and objective also answering problems faced simultaneously.
\end{abstract}

Keywords: education, Pancasila, axiology philosophy

Copyright $(2018$ Universitas Ahmad Dahlan, All Right Reserved

\section{PENDAHULUAN}

Pancasila lahir 1 Juni 1945, ditetapkan pada 18 Agustus 1945 bersamaan dengan disahkannya UUD 1945 sebagai dasar negara Indonesia. Pancasila selain sebagai ideologi negara, juga berfungsi sebagai way of life atau sebagai pandangan hidup bangsa Indonesia, jiwa bangsa Indonesia, kepribadian bangsa Indonesia, sumber dari segala sumber hukum/tertib hukum, perjanjian luhur bangsa Indonesia pada waktu mendirikan negara, cita-cita dan tujuan bangsa, dan sebagai falsafah hidup yang mempersatukan bangsa Indonesia.

Perumusan Pancasila melalui proses yang sangat panjang, dan sangat erat kaitannya dengan sejarah perjuangan bangsa Indonesia dalam mendirikan sebuah negara yang berdaulat, terlepas dari belenggu penjajah bangsa Barat. Masa penjajahan Barat sebagai tonggak sejarah perjuangan bangsa Indonesia dalam mencapai cita-citanya, sebab pada zaman penjajahan ini menyebabkan apa yang telah dimiliki bangsa Indonesia pada zaman Sriwijaya (abad VII-XII M) dan Majapahit (abad XIII-XVI M) menjadi hilang. Kedaulatan negara hilang, persatuan dihancurkan, kemakmuran lenyap, wilayah diinjak-injak penjajah. Kedua zaman ini merupakan tonggak sejarah bangsa Indonesia, karena telah memenuhi syarat sebagai bangsa yang mempunyai negara. Pada zaman itu bangsa 
Indonesia telah mengalami kehidupan yang gemah ripah loh jinawih, tata tentram, kerta raharja.

Unsur-unsur yang terdapat dalam Pancasila, yakni ketuhanan, kemanusian, persatuan, tata pemerintahan atas dasar musyawarah, keadilan sosial telah ada sebagai asas-asas yang menjiwai bangsa Indonesia yang dihayati serta dilaksanakan pada waktu itu, namun belum dirumuskan secara kongkrit. Dokumen secara tertulis ini terdapat dalam karya $\mathrm{Mpu}$ Prapanca, Nagarakartagama. Kemudian Mpu Tantular melukiskan kehidupan dua agama, yakni Hindu dan Budha secara berdampingan sebagai bukti toleransi bangsa Indonesia pada zaman itu dalam kitabnya Sutasoma (Darmodiharjo, 1991, hal. 17).

Setiap bangsa dan negara yang ingin berdiri kokoh kuat, tidak mudah terombang-ambing oleh kerasnya persoalan hidup berbangsa dan bernegara, sudah barang tentu perlu memiliki dasar negara dan ideologi negara yang kokoh dan kuat pula. Tanpa itu, maka bangsa dan negara akan rapuh. Karena itu, mempelajari Pancasila lebih dalam dapat memunculkan kesadaran diri sebagai bangsa yang memiliki jati diri. Kesadaran ini harus diwujudkan dalam pergaulan hidup sehari-hari untuk menunjukkan identitas bangsa yang lebih bermartabat dan berbudaya tinggi.

Nilai-nilai Pancasila sebagai sumber acuan dalam menyusun etika kehidupan berbangsa bagi seluruh rakyat Indonesia dalam mencapai cita-cita dan tujuan nasionalnya, maka paradigma pembangunan nasional harus berlandaskan Pancasila. Kerangka pikir, sumber nilai, orientasi dasar, sumber asas serta arah dan tujuan dari suatu perkembangan perubahan serta proses dalam suatu bidang tertentu, maka tidak boleh bertentangan dengan nilai-nilai Pancasila. Sebagai paradigma pembangunan, berarti bahwa Pancasila merupakan sumber nilai, dasar, arah dan tujuan dari proses pembangunan. Untuk itu segala aspek dalam pembangunan nasional harus mendasarkan pada hakikat nilai-nilai sila-sila Pancasila dalam mewujudkan peningkatan harkat dan martabat manusia secara konsisten berdasarkan pada nilai-nilai hakikat kodrat manusia.

\section{PEMBAHASAN}

\section{Pendidikan, Pancasila, dan aksiologi: Tinjauan konsepsional}

Pendidikan adalah usaha sadar untuk menyiapkan peserta didik melalui kegiatan bimbingan, pengajaran, dan/atau latihan bagi peranannya di masa mendatang. Pendidikan berfungsi untuk mengembangkan kemampuan serta meningkatkan mutu kehidupan dan martabat manusia Indonesia dalam rangka upaya mewujudkan tujuan nasional.

Dengan demikian, pendidikan itu harus sejalan dengan tujuan pendidikan nasional yakni mencerdaskan kehidupan bangsa dan mengembangkan manusia Indonesia seutuhnya, yaitu manusia yang beriman dan bertaqwa terhadap Tuhan Yang Maha Esa dan berbudi pekerti luhur, memiliki pengetahuan dan keterampilan, kesehatan jasmani dan rohani, kepribadian yang mantap dan mandiri serta rasa tanggung jawab kemasyarakatan dan kebangsaan.

Pendidikan merupakan upaya untuk membangun sumber daya manusia yang memerlukan wawasan luas, karena pendidikan merupakan salah satu unsur penunjang dalam kehidupan manusia sebagai wujud syukur kepada Tuhan Yang Maha Esa untuk mengolah anugerah indah yang diberikan kepada manusia berupa akal. Salah satu hal untuk mengaplikasikannya adalah setiap makhluk (manusia) memiliki hak yang sama untuk mendapatkan pendidikan yang berorientasi pada wajib belajar selama 9 tahun. Pendidikan nasional merupakan salah satu faktor penting dalam upaya meningkatkan kualitas sumber daya manusia sebagai sarana untuk mendapatkan kehidupan yang layak dan mencerdaskan kehidupan bangsa sesuai dengan yang termaktub dalam UUD Negara Republik Indonesia Tahun 1945, dan tujuan UU No. 20 Tahun 2003 tentang Sistem Pendidikan Nasional, yakni menciptakan insan yang religius, berilmu, berakhlak mulia, dan terampil.

Secara etimologis, istilah Pancasila berasal dari bahasa Sansekerta (India) bahasa kasta Brahmana, sedang bahasa rakyat biasa adalah bahasa Prakerta. Menurut Muhammad Yamin (Kaelan, 2002), secara leksikal "Pancasila" memiliki dua macam arti: "panca" (lima), "syila" (batu sendi, alas, dasar). "Syiila" (peraturan tingkah laku yang baik, yang penting).

Pancasila sebagai dasar negara Indonesia (ideologi) dan menjadi pedoman hidup (way of life), jiwa dan kepribadian bangsa Indonesia (Kaelan, 2002, hal. 1). Oleh karena itu, melalui pendididkan Pancasila, peserta didik diharapkan mampu memahami, menganalisis, dan menjawab masalah yang dihadapi secara berkesinambungan dan konsisten dengan cita-cita dan tujuan nasional dalam Pembukaan UUD 1945. Sehingga dengan demikian, Pendidikan Pancasila bertujuan untuk menghasilkan peserta didik yang beriman dan bertakwa kepada Tuhan YME, berakhlak mulia, mendukung persatuan bangsa, mengutamakan kepentingan bersama, dan berupaya mewujudkan keadilan sosial dalam masyarakat. 
Secara etimologis istilah "filsafat" berasal dari bahasa Yunani "philein" yang artinya cinta, dan "sophos" artinya hikmah atau kebijaksanaan atau wisdom. Jadi secara harfiah istilah filsafat mengandung makna cinta kebijaknaan.

Pengertian filsafat secara luas menurut Harold Titus (Jalaluddin, 2012, hal. 2) adalah sebagai berikut:

1. Filsafat adalah sekumpulan sikap dan kepercayaan terhadap kehidupan dan alam yang biasanya diterima secara kritis

2. Filsafat ialah suatu proses kritik atau pemikiran terhadap kepercayaan dan sikap yang sangat kita junjung tinggi

3. Filsafat adalah usaha untuk mendapatkan gambaran keseluruhan

4. Filsafat adalah analisis logis dari bahasan dan penjelasan tentang arti konsep

5. Filsafat adalah sekumpulan problemaproblema yang langsung mendapat perhatian manusia dan dicarikan jawabannya oleh ahli filsafat.

Senada dengan pendapat Harold Titus di atas, Barnadib (2002) menjelaskan bahwa filsafat sebagai pandangan yang menyeluruh dan sistematis. Menyeluruh karena filsafat bukan hanya pengetahuan, melainkan juga suatu pandangan yang dapat menembus sampai di balik pengetahuan itu sendiri. Dengan pandangan yang lebih terbuka ini, hubungan dan pertalian antara semua unsur yang mengarahkan perhatian dan kedalaman mengenai kebajikan dimungkinkan untuk dapat ditemukan. Sistematis, karena filsafat menggunakan berpikir secara sadar, teliti, dan teratur sesuai dengan hukum-hukum yang ada. Sehingga menurut Harun Nasution (Barnadib, 2002) dapat dikatakan bahwa filsafat berpikir menurut tata tertib (logika), bebas (tidak terikat pada tradisi, dogma, serta agama) dan dengan sedalam-dalamnya sehingga sampai ke dasar-dasar persoala.

Berdasarkan objek kajiannya, filsafat dibagi dalam tiga bidang permasalahan; metafisika, epistemologi, dan aksiologi. Atau dengan kata lain, objek kajiannya adalah Tuhan, alam dan manusia. Pemikiran filsafat dalam bidang aksiologi mengacu pada persoalan nilai, baik dalam konteks estetika, moral maupun agama. Dengan mengkaji dan menggali hakikat nilai, apakah nilai itu absolut atau relatif, bagaimana menentukan nilai, serta apakah sumber nilai itu. Sehingga dapat dikatakan bahwa akhir dari filsafat metafisika dan epistimologi ialah terwujudnya tingkah laku dan perbuatan-perbuatan manusia yang mengandung nilai. Atau dengan kata lain, apabila telaah filsafat hanya untuk mencari pemecahan masalah hakikat dan kebenaran dalam suatu realitas yang ada, maka kajiannya termasuk dalam filsafat metafisik.
Jika seseorang berupaya memberikan jawaban atas persoalan-persoalan pengetahuan pengetahuan, baik hakikat, kriteria, validitas, sumber-sumber, prosedur maupun klasifikasi dan jenis-jenis ilmu, maka dalam hal ini telaah filsafat berada dalam wilayah kajian epistemologi. Sedang jika yang menjadi fokus telaah menyangkut problem nilai atau mencari nilai-nilai yang diperlukan dan dikehendaki manusia sebagai dasar pijakan dan pegangan dalam hidup dan kehidupannya, maka kajiannya berada dalam lingkup aksiologi, yang mencakup tentang nilai kebenaran, nilai kebaikan, dan nilai keindahan. Dengan menggunakan dua pendekatan berdasarkan objek kajiannya yaitu, pertama ialah filsafat teoritis yang menekankan pada problem konseptual secara universal, dan kedua ialah filsafat teoritis yang problem penekanannya menyangkut tentang tata kehidupan serta perilaku manusia.

Filsafat teorites adalah pendekatan filsafat yang ditujukan pada persoalan-persoalan yang umum, baik tentang hakikat maupun pengetahuan. Misalnya pada bidang ontologi, kosmogoni, antropologi, epistemologi, logika, teologi, dan lain sebagainya. Kemudian filsafat praktis adalah pendekatan filsafat yang ditujukan untuk menemukan kewajiban-kewajiban, kebutuhan-kebutuhan, dan keinginan-keinginan humanitas, misalnya etika, sosiologi, filsafat sejarah, estetika, psikologi, psikologi agama, filsafat politik, dan lain-lain.

Kajian ini lebih fokus pada satu objek yakni menyangkut tentang nilai-nilai yang baik dan buruk (aksiologi), atau pendidikan yang menguji dan mengintegrasikan semua nilai tersebut dalam kehidupan manusia, kemudian nilai-nilai tersebut ditanamkan dalam kepribadian anak.

\section{Pancasila sebagai sumber nilai}

Pancasila terkandung di dalamnya suatu pemikiran-pemikiran yang bersifat kritis, mendasar, rasional, sistematis dan komprehensif, sehingga sistem pemikiran ini merupakan suatu nilai. Oleh karena itu, Pancasila memberikan dasar-dasar yang bersifat fundamental dan universal bagi manusia baik dalam hidup bermasyarakat, berbangsa, dan bernegara. Bila dijabarkan dalam kehidupan yang nyata pada masyarakat, bangsa maupun negara maka nilai tersebut dijabarkan dalam suatu normanorma yang jelas, yaitu norma moral dan norma hukum atau sistem perundangan yang berlaku di Indonesia. Istilah nilai dalam bidang filsafat dipakai untuk menunjuk kata benda abstrak "keberhargaan" atau "kebaikan", dan kata kerja yang artinya suatu tindakan kejiwaan tertentu dalam menilai atau melakukan penilaian.

Notonagoro (Kaelan, 2002) membagi nilai menjadi tiga, yaitu: 1) nilai material; segala sesuatu 
yang berguna bagi kehidupan jasmani manusia, 2) nilai vital; segala sesuatu yangg berguna bagi manusia untuk dapat mengadakan aktivitas, 3) nilai kerohanian; segala sesuatu yang berkaitan kebutuhan rohani. Sedangkan Baier (Mulyana, 2004:8) nilai sering kali dirumuskan dalam konsep yang berbeda-beda, hal tersebut disebabkan oleh sudut pandangnya yang berbeda-beda pula. Contohnya seorang sosiolog mendefinisikan nilai sebagai suatu keinginan, kebutuhan, dan kesenangan seseorang sampai pada sanksi dan tekanan dari masyarakat. Seorang psikolog akan menafsirkan nilai sebagai suatu kecenderungan perilaku yang berawal dari gejala-gejala psikologis, seperti hasrat, motif, sikap, kebutuhan dan keyakinan yang dimiliki secara individual sampai pada tahap wujud tingkah lakunya yang unik. Sementara itu, seorang antropolog melihat nilai sebagai "harga "yang melekat pada pola budaya masyarakat seperti dalam bahasa, adat kebiasaan, keyakinan, hukum dan bentuk-bentuk organisasi sosial yang dikembangkan manusia. Perbedaan pandangan mereka dalam memahami nilai telah berimplikasi pada perumusan definisi nilai. Berikut ini dikemukakan beberapa definisi nilai yang masing-masing memiliki tekanan yang berbeda.

Allport (Mulyana, 2004, hal. 9) mendefinisikan nilai sebagai sebuah keyakinan yang membuat seseorang bertindak atas dasar pilihannya. Sebagai seorang ahli psikologi kepribadian, Allport menyatakan bahwa nilai terjadi pada wilayah psikologis yang disebut keyakinan. Keyakinan merupakan wilayah psikologis tertinggi dari wilayah lainnya seperti hasrat, motif, sikap, keinginan dan kebutuhan. Oleh karenanya, keputusan benar-salah, baikburuk, indah-tidak indah pada wilayah ini merupakan hasil dari sebuah rentetan proses psikologis yang kemudian mengarahkan individu pada tindakan dan perbuatan yang sesuai dengan nilai pilihannya. Kupperman (Mulyana, 2004, hal. 9) menafsirkan nilai sebagai patokan normatif yang mempengaruhi manusia dalam menentukan pilihannya di antara cara-cara tindakan alternatif. Ia memberi penekanan pada norma sebagai faktor eksternal yang mempengaruhi perilaku manusia. Sebagai seorang sosiolog, Kupperman memandang norma sebagai salah satu bagian terpenting dari kehidupan sosial. Oleh karena itu, salah satu bagian terpenting dalam proses pertimbangan nilai (value judgement) adalah pelibatan nilai-nilai normatif yang berlaku di masyarakat. Sedangkan Kluckhohn (Brameld, 1957) mendefinisikan nilai sebagai konsepsi (tersirat atau tersurat, yang sifatnya membedakan individu atau ciri-ciri kelompok) dari apa yang diinginkan, yang mempengaruhi pilihan terhadap cara, tujuan antara dan tujuan akhir tindakan. Menurut Brameld (1957), pandangan Kulchohn tersebut memiliki banyak implikasi terhadap pemaknaan nilai-nilai budaya dan sesuatu itu dipandang bernilai apabila dipersepsi sebagai sesuatu yang diinginkan. Makanan, uang, rumah, memiliki nilai karena memiliki persepsi sebagai sesuatu yang baik dan keinginan untuk memperolehnya memiliki mempengaruhi sikap dan tingkah laku seseorang. Namun tidak hanya materi yang memiliki nilai, gagasan dan konsep juga dapat menjadi nilai, seperti: kejujuran, kebenaran dan keadilan. Kejujuran misalnya, akan menjadi sebuah nilai bagi seseorang apabila ia memiliki komitmen yang dalam terhadap nilai itu yang tercermin dalam pola pikir, tingkah laku dan sikap.

\section{Klasifikasi dan makna nilai sila-sila Pancasila}

Dalam teori nilai yang digagasnya, Spranger (Mulyana, 2004, hal. 32) menjelaskan ada enam orientasi nilai yang sering dijadikan rujukan oleh manusia dalam kehidupannya. Dalam pemunculannya, enam nilai tersebut cenderung menampilkan sosok yang khas terhadap pribadi seseorang. Nilai pertama adalah nilai teoretik. Nilai ini melibatkan pertimbangan logis dan rasional dalam memikirkan dan membuktikan kebenaran sesuatu. Nilai teoretik memiliki kadar benar-salah menurut pertimbangan akal. Oleh karena itu nilai erat dengan konsep, aksioma, dalil, prinsip, teori dan generalisasi yang diperoleh dari sejumlah dan pembuktian ilmiah. Komunitas manusia yang tertarik pada nilai ini adalah para filosof dan ilmuwan.

Nilai kedua adalah nilai ekonomis yang terkait dengan pertimbangan nilai yang berkadar untungrugi. Objek yang ditimbangnya adalah "harga" dari suatu barang atau jasa. Karena itu, nilai ini lebih mengutamakan kegunaan sesuatu bagi kehidupan manusia. Oleh karena pertimbangan nilai ini relatif pragmatis, Spranger melihat bahwa dalam kehidupan manusia seringkali terjadi konflik antara kebutuhan nilai ekonomis ini dengan nilai lainnya. Kelompok manusia yang tertarik nilai ini adalah para pengusaha dan ekonomi.

Nilai ketiga adalah nilai estetik yang menempatkan nilai tertingginya pada bentuk dan keharmonisan. Apabila nilai ini ditilik dari subyek yang memiliknya, maka akan muncul kesan indahtidak indah. Nilai estetik berbeda dengan nilai teoretik. Nilai estetik lebih mengandalkan pada hasil penilaian pribadi seseorang yang bersifat subyektif, sedangkan nilai teroretik lebih melibatkan penilaian obyektif yang diambil dari kesimpulan atas sejumlah fakta kehidupan. Nilai estetik banyak dimiliki oleh para seniman seperti musisi, pelukis, atau perancang model.

Nilai keempat adalah nilai sosial. Nilai tertinggi dari nilai ini adalah kasih sayang di antara manusia. Karena itu kadar nilai ini bergerak pada rentang kehidupan yang individualistik dengan 
yang altruistik. Sikap yang tidak berpraduga jelek terhadap orang lain, sosiabilitas, keramahan, serta perasaan simpati dan empati merupakan kunci keberhasilan dalam meraih nilai sosial. Nilai sosial ini banyak dijadikan pegangan hidup bagi orang yang senang bergaul, suka berderma, dan cinta sesama manusia.

Nilai kelima adalah nilai politik. Nilai tertinggi dalam nilai ini adalah kekuasaan. Karena itu, kadar nilainya akan bergerak dari intensitas pengaruh yang rendah sampai pengaruh yang tinggi (otoriter). Kekuatan merupakan faktor penting yang berpengaruh pada diri seseorang. Sebaliknya, kelemahan adalah bukti dari seseorang kurang tertarik pada nilai ini. Dilihat dari kadar kepemilikannya nilai politik memang menjadi tujuan utama orang-orang tertentu seperti para politisi dan penguasa.

Nilai keenam adalah nilai agama. Secara hakiki sebenarnya nilai ini merupakan nilai yang memiliki dasar kebenaran yang paling kuat dibandingkan dengan nilai-nilai sebelumnya. Nilai ini bersumber dari kebenaran tertinggi yang datangnya dari Tuhan. Nilai tertinggi yang harus dicapai adalah kesatuan (unity). Kesatuan berarti adanya keselarasan semua unsur kehidupan, antara kehendak manusia dengan kehendak Tuhan, antara ucapan dengan tindakan, antara i'tikad dengan perbuatan. Spranger melihat bahwa pada sisi nilai inilah kesatuan filsafat hidup dapat dicapai. Di antara kelompok manusia yang memiliki orientasi kuat terhadap nilai ini adalah para nabi, imam, atau orang-orang sholeh.

Menurut Scheler (Wahana, 2008), nilai dalam kenyataannya ada yang lebih tinggi dan ada juga yang lebih rendah jika dibandingkan dengan yang lainnya. Oleh karena itu, nilai menurut Scheler (Mulyana, 2004, hal. 38) memiliki hierarki yang dapat dikelompokkan ke dalam empat tingkatan, yaitu nilai kenikmatan, nilai kehidupan, nilai kejiwaan, dan nilai kerohanian. Pada nilai kenikmatan, terdapat sederet nilai yang menyenangkan atau sebaliknya yang kemudian orang merasa bahagia atau menderita. Pada nilai kehidupan, terdapat nilai-nilai yang penting bagi kehidupan, misalnya kesehatan, kesegaran badan, kesejahteraan umum dan lain-lain. Pada nilai kejiwaan terdapat nilai kejiwaan yang sama sekali tidak bergantung pada keadaan jasmani atau lingkungan, yaitu keindahan, kebenaran dan pengetahuan murni yang dicapai melalui filsafat. Terakhir, pada nilai kerohanian terdapat nilai yang suci maupun tidak suci. Nilai-nilai ini terutama lahir dari ketuhanan sebagai nilai tertinggi. Hierarki nilai tersebut ditetapkan Scheler dengan menggunakan empat kriteria, yaitu: semakin lama semakin tinggi tingkatannya; semakin dapat dibagikan tanpa mengurangi maknanya, semakin tinggi nilainya; semakin tidak tergantung pada nilai-nilai lain, semakin tinggi esensinya; semakin membahagiakan, semakin tinggi fungsinya.

Pancasila telah diyakini kebenarannya oleh bangsa Indonesia. Oleh karena itu, mengamalkan Pancasila merupakan suatu keharusan bagi bangsa Indonesia. Masing-masing sila Pancasila memiliki makna tersendiri. Arti dan makna Sila Ketuhanan Yang Maha Esa adalah sebagai berikut:

1. Mengandung arti pengakuan adanya kausa prima (sebab pertama) yaitu Tuhan Yang Maha Esa

2. Menjamin penduduk untuk memeluk agama masing-masing dan beribadah menurut agamanya.

3. Tidak memaksa warga negara untuk beragama.

4. Menjamin berkembang dan tumbuh suburnya kehidupan beragama.

5. Bertoleransi dalam beragama, dalam hal ini toleransi ditekankan dalam beribadah menurut agamanya masing-masing.

6. Negara memberi fasilitator bagi tumbuh kembangnya agama dan iman warga negara dan mediator ketika terjadi konflik agama.

Arti dan makna sila Kemanusiaan yang adil dan beradab adalah:

1. Menempatkan manusia sesuai dengan hakikatnya sebagai makhluk Tuhan

2. Menjunjung tinggi kemerdekaan sebagai hak segala bangsa.

3. Mewujudkan keadilan dan peradaban yang tidak lemah.

Arti dan makna Sila Persatuan Indonesia:

1. Nasionalisme.

2. Cinta bangsa dan tanah air.

3. Menggalang persatuan dan kesatuan Indonesia.

4. Menghilangkan penonjolan kekuatan atau kekuasaan, keturunan dan perbedaan warna kulit.

5. Menumbuhkan rasa senasib dan sepenanggungan.

Arti dan makna sila Kerakyatan yang dipimpin oleh hikmat kebijaksanaan dalam permusyawaratan/perwakilan:

1. Hakikat sila ini adalah demokrasi

2. Permusyawaratan, artinya mengusahakan putusan bersama secara bulat, baru sesudah itu diadakan tindakan bersama.

3. Dalam melaksanakan keputusan diperlukan kejujuran bersama. 
Arti dan makna sila Keadilan sosial bagi seluruh rakyat Indonesia:

1. Kemakmuran yang merata bagi seluruh rakyat dalam arti dinamis dan meningkat.

2. Seluruh kekayaan alam dan sebagainya dipergunakan bagi kebahagiaan bersama menurut potensi masing-masing.

3. Melindungi yang lemah agar kelompok warga masyarakat dapat bekerja sesuai dengan bidangnya.

Dalam hubungannya dengan filsafat, nilai merupakan salah satu hasil pemikiran filsafat yang pemikirannya dianggap sebagai hasil maksimal yang paling benar. Dalam bidang operasional nilainilai ini dijabarkan dalm bentuk kaidah/norma/ ukuran (normatif), sehingga merupakan suatu perintah atau larangan.

Adapun nialai-nilai yang terkandung di dalam sila-sila Pancasila sebagaimana diuraikan Kaelan (Kaelan, 2002) adalah sebagai berikut: Sila Ketuhanan Yang Maha Esa terkandung nilai religius yaitu; 1) keyakinan terhadap adanya Tuhan Yang Maha Esa dengan sifat-sifat-Nya yang maha sempurna, maha kasih, maha kuasa, maha adil, maha bijaksana, dan lain-lain sifat yang suci, 2) ketaqwaan adanya Tuhan Yang Maha Esa menjalankan semua perintahnya dan menjauhi segala larangannya. Sila Ketuhanan Yang Maha Esa sebagai sumber ajaran moral dasar (basic morality). Apabila ditelaah secara mendalam terhadap definisi filsafat hidup atau weltanschauung, jelaslah bahwa sesungguhnya di dalam kerangka pengertian filsafat hidup telah dipermasalahkan pula apa yang disebut dengan ajaran nilai (doctrine of value). Salah satu obyek yang dibahas dalam filsafat hidup adalah menyangkut persoalan moral dalam arti moral dasar. Menurut Muhammad Rasjidi (Kaelan, 2002) yang dimaksud moral dasar ialah suatu aturan yang mendasar, yang kita rasakan tidak mungkin dapat menyangkalnya, Oleh karena itu ia dapat dijadikan pedoman kita dalam keadaan yang berbeda-beda. Notonagoro (Kaelan, 2002) menyatakan bahwa hakikat filsafat Pancasila itu merupakan bentuk pemadatan atau kristalisasi dari keyakinan hidup beragama bangsa Indonesia serta adat istiadat dan kebudayaan bangsa. Sehingga jika dianalisa maka 'moral dasar' yang terkandung dalam Filsafat Pancasila menyatakan bahwa 'dengan singkat haruslah dikatakan' bahwa ketuhanan adalah dasar dan tujuan dari seluruh kesusilaan. Tanpa ketuhanan tidak mungkin ada kesusilaan yang berkembang batul-betul.

Sila Kemanusiaan yang adil dan beradab terkandung nilai-nilai kemanusiaan yaitu; 1) pengakuan adanya martabat manusi, 2) perlakuan yang adil terhadap sesama manuasia, 3) pengertian yang beradab yang memiliki daya cipta, rasa karsa, dan keyakinan sehingga jelas adanya perbedaan antara manusia dan hewan. Sila Persatuan Indonesia terkandung nilai-nilai persatuan antara lain; 1) persatuan bangsa yang mendiami wilayah Indonesia, 2) Indonesia adalah bangsa yang terdiri atas berbagai suku yang mendiami wilayah Indonesia sehingga persatuan sangat perlu untuk menyatukannya atau pengakuan terhadap "Bhinneka Tunggal Ika".

Sila Kerakyatan yang dipimpin oleh hikmat kebijaksanaan dalam permusyawaratan/perwakilan terkandung nilai kerakyatan antara lain: 1) kedaulatan negara adalah ditangan rakyat, 2) pimpinan kerakyatan adalah hikmat kebijaksanaan yang dilandasi akal sehat, 3) warga negara dan warga masyarakat Indonesia mempunyai kedudukan, hak, kewajiban yang sama, 4) musyawarah untuk mufakat.

Sila Keadilan sosial bagi seluruh rakyat Indonesia terkandung nilai sosial antara lain: 1) perwujudan keadilan social dalm kehidupan sosial atau kemasyarakatan meliputi seluruh rakyat Indonesia, 2) keadilan dalam kehidupan sosial meliputi bidang-bidang ideology, politik, ekonomi, sosial kebudayaan dan pertahanan keamanan nasional, 3) cita-cita masyarakat adail makmur, material,dan spiritual yang merata bagi seluruh rakyat Indonesia, 4) keseimbangan antara hak dan kewajiban dan menghormati hak orang lain, cinta akan kemajuan dan pembangunan.

\section{Hubungan Filsafat, Pendidikan, dan Pancasila}

Manusia merupakan subjek dan sekaligus sebagai objek pendidikan, karena itu manusia memiliki sikap untuk dididik dan siap untuk mendidik. Akan tetapi, sukses tidaknya usaha tersebut tergantung pada jelas tidaknya tujuan. Oleh karena itu, tujuan pendidikan harus berlandaskan pada filsafat hidup bangsa, yaitu Pancasila sebagai pokok dalam pendidikan, melalui usaha-usaha pendidikan baik dalam keluarga, masyarakat, sekolah, maupun di perguruan tinggi.

Filsafat pendidikan adalah nilai-nilai dan keyakinan-keyakinan fisafat yang menjiwai, mendasari dan memberikan identitas (karakteristik) suatu sistem pendidikan. Filsafat pendidikan adalah jiwa, roh dan kepribadian sistem pendidikan nasional, sehingga sistem pendidikan nasional idealnya dijiwai didasari dan mencerminkan identitas Pancasila, citra dan karsa bangsa Indonesia sebagaimana yang yang tercantum dalam Pembukaan UUD 1945, sebagai perwujudan jiwa dan nilai Pancasila.

Secara praktis pendidikan tidak dapat dipisahkan dengan nilai-nilai, terutama yang meliputi kualitas kecerdasan, nilai ilmiah, nilai moral, dan nilai agama yang kesemuanya tersimpul dalam 
tujuan pendidikan, yakni membina kepribadian ideal (Jalaluddin, 2012, hal. 136). Tujuan pendidikan baik pada isinya maupun rumusannya, tidak akan mungkin dapat ditetapkan tanpa pengertian dan pengetahuan yang tepat tentang nilai-nilai.

Sistem pendidikan bertumpu dan dijiwai oleh suatu keyakinan, pandangan hidup dan filosofis tertentu. Pemikiran inilah yang mendasari akan pentingnya filsafat pendidikan Pancasila yang merupakan tuntutan nasional. Oleh karena filsafat Pancasila merupakan satu kesatuan bulat dan utuh, atau kesatuan organik yang berlandaskan pada Pancasila. Filsafat menjadikan manusia berkembang dan mempunyai pandangan hidup yang menyeluruh dan sistematis. Pandangan itu kemudian dituangkan dalam sistem pendidikan, untuk mengarahkan tujuan pendidikan. Penuangan pemikiran ini dalam bentuk Kurikulum. Melalui kurikulum, sistem pengajaran dapat terarah, selain dapat mempermudah para pendidik dalam menyusun pengajaran yang akan diberikan kepada peserta didik.

Sehingga dengan demikian dapat disimpulkan bahwa hubungan filsafat, pendidikan, dan Pancasila, dimana filsafat adalah berfikir secara mendalam dan sungguh-sungguh untuk mencari kebenaran sesuatu, sedangkan pendidikan adalah suatu usaha yang dilaksanakan secara sadar melalui pemikiran yang mendalam berdasarkan filsafat. Lalu jika dihubungkan fungsi Pancasila dengan sistem pendidikan ditinjau filsafat aksiologi, maka dapat dijabarkan bahwa Pancasila adalah pedoman hidup bangsa Indonesia yang mengandung tentang nilai-nilai sebagai acuan dalam menjalani hidup dan kehidupan.

\section{KESIMPULAN}

Pancasila adalah dasar negara Indonesia yang merupakan fungsi utamanya dan dari segi materinya digali dari pandangan hidup dan kepribadian bangsa. Pancasila adalah dasar negara bangsa Indonesia yang mempunyai fungi dalam hidup dan kehidupan bangsa dan negara Indonesia tidak saja sebagai negara RI, tetapi juga alat pemersatu bangsa, jiwa seluruh rakyat Indonesia, kepribadian bangsa Indonesia, pandangan bangsa Indonesia dan sumber dari segala sumber hukum, serta sumber pengetahuan. Pancasila juga merupakan kebudayaan mengajarkan tentang hidup manusia akan mencapai puncak kebahagiaan jika dapat dikembangkan keselarasan dan keseimbangan, baik dalam hidup manusia sebagai pribadi, sebagai makhluk sosial dalam mengejar hubungan dengan masyarakat, alam, Tuhannya maupun dalam mengejar kemajuan lahiriah dan kebahagiaan rohaniah. Oleh karena itu, perlu memahami, menghayati dan mengamalkan Pancasila dalam kehidupan sehari-hari. Tanpa upaya tersebut,
Pancasila hanya akan menjadi rangkaian kata-kata indah dan rumusan yang beku dan mati serta tidak mempunyai arti bagi kehidupan bangsa Indonesia.

Manusia sebagai individu, sebagai masyarakat, sebagai bangsa dan negara, hidup dalam ruang sosial budaya. Aktivitas untuk mewariskan dan mengembangkan sosial budaya itu terutama melalui pendidikan. Untuk menjamin supaya pendidikan itu benar dan prosesnya efektif, dibutuhkan landasan-landasan filosofis dan ilmiah sebagai asas normatif dan pedoman pelaksanaan pembinaan. Dengan demikian, kedua asas tersebut tidak dapat dipisahkan. Sebab, pendidikan merupakan usaha membina dan mewariskan kebudayaan, mengemban suatu kewajiban yang luas dan menentukan prestasi suatu bangsa bahkan tingkat sosio budaya mereka (Budimansyah, 2011, hal. 37).

Pancasila sebagai filsafat hidup bangsa, oleh karena nilai-nilai dasar dalam sosio budaya Indonesia hidup dan berkembang sejak awal peradabannya, yang meliputi: 1) kesadaran keberagamaan, 2) kekeluargaan, 3) musyawarah mufakat dalam menetapkan kehendak bersama, 4) kesadaran gotong royong, dan tolong menolong, serta 5) tenggang rasa.

Keadaan masyarakat dapat diukur melalui melalui pendidikan. Sehingga kerusakan pada semua aspek dalam masyarakat tidak dapat diperbaiki dengan cara apa pun kecuali dengan pendidikan menurut Plato (Jalaluddin, 2012, hal. 137)

Nilai dan implikasi aksiologi terbentuk atas dasar pertimbangan-pertimbangan cipta, rasa, karsa dan keyakinan seseorang atau kelompok masyarakat atau Bangsa. Norma kaidah adalah petunjuk tingkah laku yang harus dilakukan dan tidak boleh dalam kehidupan sehari-hari dengan disertai sanksi. Sanksi adalah ancaman atau akibat yang diterima apabila norma (kaidah) tidak dilakukan. Dari hubungan nilai,norma dan sanksi ini timbulah macam-macam norma dan saksinya antara lain: 1) Norma agama dengan sanksi agama, 2) Norma kesusilaan dengan sanksi rasa susila, 3) Norma sopan santun, dengan sanksi sosial dari masyarakat, 4) Norma hukum, dengan sanksi hukum dari pemerintah.

Nilai-nilai Pancasila telah diyakini kebenarannya oleh bangsa Indonesia. Oleh karena itu mengamalkan Pancasila merupakan suatu keharusan bagi bangsa Indonesia. Sikap positif dalam mengamalkan nilai-nilai Pancasila: 1) menghormati anggota keluarga, 2) menghormati orang yang lebih tua, 3) membiasakan hidup hemat, 4) tidak membeda-bedakan teman, membiasakan musyawarah untuk mufakat, 5) menjalankan ibadah sesuai dengan agama masing-masing, 6) membantu 
orang lain yang kesusahan sesuai dengan kemampuan sendiri.

Pancasila sebagai pandangan hidup bangsa yang menjiwai sila-silanya dalam kehidupan seharihari. Untuk menerapkan sila-sila Pancasila, diperlukan pemikiran yang sungguh-sungguh tentang bagaimana nilai-nilai Pancasila itu dapat dilaksanakan. Dalam hal ini pendidikanlah yang mempunyai peran utama.

\section{DAFTAR PUSTAKA}

Barnadib, I. (2002). Filsafat Pendidikan. Yogyakarta: AdiCita.

Brameld, T. (1957). Cultural foundation of education: An interdisciplinary exploration. New York: Harper.

Budimansyah, D. (2011). Aktualisasi nilai-nilai Pancasila dalam membangun karakter warga negara. Bandung: Widya Aksara Press.

Darmodiharjo, D. (1991). Santiaji Pancasila: Tinjauan filosofis, historis dan yuridiskonstitusional. Surabaya: Usaha Nasional.

Jalaluddin. (2012). Filsafat pendidikan. Jakarta: RajaGrafindo Persada.

Kaelan. (2002). Filsafat Pancasila: Pandangan hidup bangsa Indonesia. Yogyakarta: Paradigma.

Mulyana, R. (2004). Mengartikulasikan pendidikan nilai. Bandung: Alfabeta.

Wahana, P. (2008). Nilai etika aksiologis Max Scheler. Yogyakarta: Kanisius. 